\title{
Gambaran kadar natrium dan klorida pada pasien penyakit ginjal kronik stadium 5 non-dialisis
}

\author{
${ }^{1}$ Ryan Y. Tambajong \\ ${ }^{2}$ Glady I. Rambert \\ ${ }^{2}$ Mayer F. Wowor
}

\author{
${ }^{1}$ Kandidat Skripsi Fakultas Kedokteran Universitas Sam Ratulangi Manado \\ ${ }^{2}$ Bagian Patologi Klinik Fakultas Kedokteran Universitas Sam Ratulangi Manado \\ Email: ryantambajong12214@gmail.com
}

\begin{abstract}
Chronic kidney disease (CKD) is a pathophysiological process with a variety of etiology, causing a progressive decline in kidney function, and generally ends with kidney failure. Although significant progress has been made for the treatment of CKD, it was not satisfying yet, especially at the final stage of the disease. Reducing salt intake is one of the options. Approximately, 60\% of non-dialysis CKD patients suffered from hyponatremia with normal chloride levels. This study aimed to obtain the profile of the sodium and chloride levels in non-dialysis CKD patients. This was a descriptive study and was carried out at two hospitals, Prof. Dr. R. D. Kandou Hospital Manado and Advent Hospital Manado. Samples were blood samples of 35 patients suffering from stage 5 non-dialysis CKD determined by using consecutive sampling of non-probability sampling model. The results showed that based on the laboratory result, there were 19 patients diagnosed with stage 5 non-dialysis CKD with hyponatremia (54.3\%) and 19 patients with imbalance chloride levels consisted of 8 patients with hypochloremia (22.9\%) and 8 patients with hyperchloremia (22.9\%). Conclusion: In stage five non-dialysis chronic kidney disease patients, sodium and chloride imbalance commonly occurred as hyponatremia, however, hypo and hyperchloremia had the same occurence.
\end{abstract}

Keywords: sodium level, chloride level, stage 5 chronic kidney disease, non-dialysis

\begin{abstract}
Abstrak: Penyakit ginjal kronik (PGK) adalah suatu proses patofisologis dengan etiologi beragam, mengakibatkan penurunan fungsi ginjal yang progresif, dan umumnya berakhir dengan gagal ginjal. Meskipun kemajuan signifikan telah diperoleh dalam pengobatan PGK, hasil pengobatan tersebut belum memuaskan, terutama pada pasien dengan tahap akhir penyakit. Pengurangan asupan garam ialah salah satu opsi tersebut. Sekitar $60 \%$ dari pasien PGK non-dialisis mengalami hiponatremia dengan kadar klorida yang masih normal. Penelitian ini bertujuan untuk mengetahui gambaran kadar natrium dan klorida pada pasien PGK stadium 5 non-dialisis. Jenis penelitan ini deskriptif. Penelitian dilakukan pada dua rumah sakit, yaitu RSUP Prof. Dr. R. D. Kandou Manado dan Rumah Sakit Advent Manado. Sampel penelitian ialah sampel darah dari 35 pasien yang menderita PGK stadium 5 nondialisis yang ditentukan dengan cara non-probability sampling jenis consecutive sampling. Hasil penelitian memperlihatkan bahwa berdasarkan hasil pemeriksaan laboratorium yang dilakukan terdapat 19 pasien (54,3\%) yang terdiagnosis PGK stadium 5 non-dialisis mengalami hiponatremia dan 19 pasien mengalami gangguan keseimbangan kadar klorida, yang terdiri dari 8 pasien (22,9\%) mengalami hipokloremia dan 8 pasien (22,9\%) mengalami hiperkloremia. Simpulan: Pada pasien penyakit ginjal kronik stadium 5 non-dialisis, gangguan keseimbangan kadar natrium dan klorida yang sering terjadi ialah hiponatremia, sedangkan kejadian hipokloremia dan hiperkloremia ditemukan sama banyak.
\end{abstract}

Kata kunci: kadar natrium, kadar klorida, penyakit ginjal kronik stadium 5, non dialisis 
Penyakit ginjal kronik (PGK) adalah suatu proses patofisologis dengan etiologi yang beragam, mengakibatkan penurunan fungsi ginjal yang progresif, dan pada umumnya berakhir dengan gagal ginjal. Gagal ginjal adalah suatu keadaan klinis yang ditandai dengan penurunan fungsi ginjal yang irreversible. Pada penyakit ginjal kronik stadium 5 memerlukan beberapa tindakan, berupa hemodialisis atau transplantasi ginjal. $^{1}$

Meskipun kemajuan signifikan telah diperoleh dalam pengobatan penyakit ginjal kronis, pengobatan belum memuaskan, terutama pada tahap akhir penyakit Intervensi untuk mengurangi beban penyakit tersebut yang seharusnya dilakukan. Pengurangan asupan garam merupakan salah satu opsi tersebut. Pemahaman yang lebih baik dari efek merusak garam pada kesehatan ginjal perlu untuk meningkatkan kesadaran akan pentingnya pengurangan kandungan garam. Garam adalah senyawa yang terdiri dari ion natrium dan klorida. ${ }^{2}$

Natrium ialah kation terbanyak dalam cairan ekstrasel, jumlahnya bisa mencapai $60 \mathrm{mmol}$ per $\mathrm{kg}$ berat badan dan sebagian kecil (sekitar 10-14 mmol/L) berada dalam cairan intrasel. Dalam keadaan normal, ekskresi natrium pada ginjal diatur sehingga keseimbangan dipertahankan antara asupan dan pengeluaran dengan volume cairan ekstrasel tetap stabil. Lebih dari 90\% tekanan osmotik di cairan ekstrasel ditentukan oleh garam, khususnya dalam bentuk natrium klorida $(\mathrm{NaCl})$ dan natrium bikarbonat (NaHCO3) sehingga perubahan tekanan osmotik pada cairan ekstrasel menggambarkan perubahan konsentrasi natrium. Perbedaan kadar natrium dalam cairan ekstrasel dan intrasel disebabkan oleh adanya transpor aktif dari natrium keluar sel yang bertukar dengan masuknya kalium ke dalam sel (pompa $\mathrm{Na}^{+}$ $\mathrm{K}^{+}$). Jumlah natrium dalam tubuh merupakan gambaran keseimbangan antara natrium yang masuk dan natrium yang dikeluarkan. Kadar natrium normal dalam tubuh ialah 135-145 mmol/L. Pemasukan natrium yang berasal dari diet melalui epitel mukosa saluran cerna dengan proses difusi dan pengeluarannya melalui ginjal, saluran cerna atau keringat di kulit. ${ }^{3}$

Klorida merupakan anion utama dalam cairan ekstrasel. Jumlah klorida pada orang dewasa normal sekitar $30 \mathrm{mmol}$ per $\mathrm{kg}$ berat badan. Sekitar 88\% klorida berada dalam cairan ekstrasel dan 12\% dalam cairan intrasel. Konsentrasi klorida pada bayi lebih tinggi dibandingkan pada anakanak dan dewasa. Keseimbangan GibbsDonnan mengakibatkan kadar klorida dalam cairan interstisial lebih tinggi dibanding dalam plasma. Klorida dapat menembus membran sel secara pasif. Perbedaan kadar klorida antara cairan interstisial dan cairan intrasel disebabkan oleh perbedaan potensial di permukaan luar dan dalam membran sel. ${ }^{3}$

Jumlah klorida dalam tubuh ditentukan oleh keseimbangan antara klorida yang masuk dan yang keluar. Klorida yang masuk tergantung dari jumlah dan jenis makanan. Kandungan klorida dalam makanan sama dengan natrium. Orang dewasa pada keadaan normal rerata mengkonsumsi 50-200 mmol klorida per hari, dan ekskresi klorida bersama feses sekitar 1-2 mmol perhari. Drainase lambung atau usus pada diare menyebabkan ekskresi klorida mencapai $100 \mathrm{mmol}$ perhari. Kadar klorida dalam keringat bervariasi, rerata $40 \mathrm{mmol} / \mathrm{L}$. Pada pengeluaran keringat berlebihan, kehilangan klorida dapat mencapai $200 \mathrm{mmol}$ per hari. $^{3}$

Gangguan keseimbangan natrium yang dapat terjadi pada PGK ialah hiponatremia dan hipernatremia, ${ }^{4}$ sedangkan gangguan kesimbangan klorida yang dapat terjadi pada PGK ialah hipokloremia dan hiperkloremia. ${ }^{5}$

\section{METODE PENELITIAN}

Jenis penelitian ialah deskriptif dengan desain potong lintang. Penelitian ini dilaksanakan di dua rumah sakit yaitu Poliklinik Nefrologi-Hipertensi dan rawat inap bagian Penyakit Dalam RSUP Prof. Dr. R. D. Kandou Manado dan Rumah Sakit Advent Manado selama bulan 
Desember 2015 sampai Januari 2016. Sampel penelitian ialah sampel darah dari semua pasien PGK stadium 5 non-dialisis dalam kurun waktu dan kriteria yang telah ditentukan dengan cara non-probability sampling jenis consecutive sampling. Jumlah sampel yang didapat pada penelitian ini ialah 35 pasien PGK diantaranya 18 pasien rawat inap dan 17 pasien rawat jalan yang memenuhi kriteria inklusi.

\section{HASIL PENELITIAN}

Tabel 1. Distribusi pasien penyakit ginjal kronik menurut usia

\begin{tabular}{ccc}
\hline Usia & Jumlah & $\%$ \\
\hline 26-35 Tahun & 1 & 2,9 \\
36-45 Tahun & 2 & 5,7 \\
46-55 Tahun & 8 & 22,9 \\
56-65 Tahun & 7 & 20,0 \\
66-75 Tahun & 13 & 37,1 \\
>75 Tahun & 4 & 11,4 \\
Jumlah & 35 & 100,0 \\
\hline
\end{tabular}

Tabel 2. Distribusi pasien menurut jenis kelamin

\begin{tabular}{ccc}
\hline Jenis kelamin & Frekuensi & $\%$ \\
\hline Laki-Laki & 21 & 60,0 \\
Perempuan & 14 & 40,0 \\
Total & 35 & 100,0 \\
\hline
\end{tabular}

Tabel 3. Distribusi menurut riwayat penyakit dahulu

\begin{tabular}{lcc}
\hline $\begin{array}{c}\text { Riwayat penyakit } \\
\text { dahulu }\end{array}$ & Frekuensi & $\%$ \\
\hline Hipertensi & 29 & 83 \\
Diabetes melitus & 8 & 23 \\
Asam urat & 15 & 43 \\
\hline
\end{tabular}

Tabel 4. Distribusi menurut hasil pemeriksaan natrium

\begin{tabular}{ccc}
\hline \multirow{2}{*}{ Kadar natrium } & \multicolumn{2}{c}{ Frekuensi } \\
\cline { 2 - 3 } & Jumlah & $\%$ \\
\hline Hiponatremia & 19 & 54,3 \\
Normal & 10 & 28,6 \\
Hipernatremia & 6 & 17,1 \\
Total & 35 & 100,0 \\
\hline
\end{tabular}

Tabel 5. Distribusi kadar natrium menurut pelayanan medis

\begin{tabular}{ccccc}
\hline \multirow{2}{*}{$\begin{array}{c}\text { Pelayanan } \\
\text { medis }\end{array}$} & $\begin{array}{c}\text { Hipo- } \\
\text { natremia }\end{array}$ & Normal & $\begin{array}{c}\text { Hiper- } \\
\text { natremia }\end{array}$ & Total \\
\hline $\begin{array}{c}\text { Rawat } \\
\text { jalan }\end{array}$ & 9 & 5 & 3 & 17 \\
$\begin{array}{c}\text { Rawat } \\
\text { inap }\end{array}$ & 10 & 5 & 3 & 18 \\
\hline
\end{tabular}

Tabel 6. Distribusi menurut hasil pemeriksaan klorida

\begin{tabular}{ccc}
\hline \multirow{2}{*}{ Kadar klorida } & \multicolumn{2}{c}{ Frekuensi } \\
\cline { 2 - 3 } & Jumlah & $\%$ \\
\hline Hipokloremia & 8 & 22,9 \\
Normal & 19 & 54,2 \\
Hiperkloremia & 8 & 22,9 \\
Total & 35 & 100,0 \\
\hline
\end{tabular}

Tabel 7. Distribusi kadar klorida menurut pelayanan medis

\begin{tabular}{ccccc}
\hline \multirow{2}{*}{$\begin{array}{c}\text { Pelayanan } \\
\text { medis }\end{array}$} & $\begin{array}{c}\text { Kipo- } \\
\text { kloremia }\end{array}$ & Normal & $\begin{array}{c}\text { Hiper- } \\
\text { kloremia }\end{array}$ & Total \\
\cline { 2 - 5 } & 4 & 10 & 4 & 17 \\
$\begin{array}{c}\text { Rawat } \\
\text { jalan }\end{array}$ & 4 & 9 & 4 & 18 \\
Rawat inap & 4 & 9 &
\end{tabular}

\section{BAHASAN}

Berdasarkan data distribusi usia pada Tabel 5, kelompok usia 66-75 tahun (37,1\%) merupakan kelompok usia terbanyak yang menderita PGK stadium 5 non-dialisis dan yang paling sedikit ialah kelompok usia 26-35 tahun (2,9\%).

Berbeda dengan hasil di atas, distribusi pasien PGK stadium 5 non-dialisis berdasarkan usia menurut hasil data statistik United States Renal Data System pada tahun 2013 menunjukkan bahwa kelompok usia 45-64 tahun merupakan kelompok usia dengan prevalensi terbanyak yang menderita PGK stadium 5 yaitu sebesar 292.344 kasus di Amerika. ${ }^{6}$ Hasil penelitian ini juga berbeda dengan yang dipublikasikan oleh Kementrian Kesehatan dalam data Riset Kesehatan Dasar (RISKESDAS) tahun 2013 yang menunjukkan bahwa jumlah pasien 
tertinggi terdapat pada kelompok umur $\geq 75$ tahun $(0,6 \%)$.

Distribusi pasien PGK stadium 5 nondialisis berdasarkan jenis kelamin pada Tabel 6 menunjukkan bahwa prevalensi PGK stadium 5, baik pasien yang rawat inap ataupun rawat jalan didapatkan bahwa pasien laki-laki lebih tinggi yaitu 21 orang (60,0\%) dibandingkan pasien perempuan yaitu 14 orang $(40,0 \%)$. Hal ini sesuai dengan data statistik United States Renal Data System (USRDS) menunjukkan bahwa pasien laki-laki $(56,8 \%)$ lebih banyak dari perempuan $(43,2 \%){ }^{6}$

Berdasarkan Tabel 7, dari 35 pasien yang terdiagnosis PGK stadium 5 nondialisis, terdapat 29 orang dengan riwayat hipertensi (83\%), 8 orang dengan riwayat diabetes melitus (23\%), 15 orang dengan riwayat asam urat (43\%). Berdasarkan pembagian ini dapat dilihat bahwa hipertensi merupakan riwayat penyakit dahulu yang terbanyak pada pasien PGK stadium 5 non-dialisis. Hasil ini berbeda dengan data statistik United States Renal Data System Annual Data Report (2013) ${ }^{8}$ yang menunjukkan bahwa diabetes $(37,9 \%)$ merupakan penyebab terbanyak PGK stadium 5. Berbeda dengan data di atas, hasil penelitian ini sejalan dengan data statistik $5^{\text {th }}$ Report Indonesian Renal Registry tahun 2012 menunjukkan bahwa frekuensi pasien dengan hipertensi yang tertinggi pada PGK stadium 5 yaitu sebesar 5.654 kasus disusul dengan diabetes sebesar 4.199 kasus yang sesuai dengan data statistik yang menunjukkan bahwa hipertensi (34\%) merupakan penyebab terbanyak PGK stadium $5 .^{9}$

Penyakit ginjal kronis didefinisikan sebagai kerusakan ginjal persisten disertai dengan penurunan glomerular yang laju filtrasi (GFR). Peningkatan kejadian PGK terjadi pada lanjut usia, hipertensi, diabetes, dan obesitas dalam populasi di Amerika Serikat. Hipertensi telah dilaporkan terjadi 85\%-95\% dari pasien dengan PGK tahap 35. Hipertensi yang tidak terkontrol merupakan faktor risiko untuk peningkatan jumlah kasus yang lebih cepat. ${ }^{10}$

Berdasarkan Tabel 8, terdapat 19 orang
(54,3\%) yang mengalami penurunan natrium (hiponatremia) yang menjadi populasi terbanyak dalam penelitian ini sedangkan 10 orang dengan kadar natrium masih normal (28,6\%), dan 6 orang mengalami peningkatan kadar natrium (17,1\%). Menurut Kovesdy, ${ }^{11}$ pasien dengan PGK (CKD) mungkin lebih rentan terhadap gangguan kadar klorida yang diakibatkan oleh kurangnya kemampuan untuk mempertahankan homeostasis air dalam menghadapi penurunan fungsi ginjal. Kovesdy meneliti hubungan tingkat natrium serum diukur berulang kali dari waktu ke waktu dengan semua penyebab kematian dalam sebuah studi kohort dari veteran AS dengan PGK non-dialisis. Penelitian juga dilakukan untuk mecari hubungan antara hiponatremia dan hipernatremia. Hasil penelitian di Amerika Serikat menunjukkan $42 \%$ dari 655.493 pasien PGK yang diteliti mengalami hiponatremia. Kovesdy menyimpulkan bahwa hiponatremia dan hipernatremia berhubungan dengan penyebab kematian pada pasien PGK non-dialisis. Penelitian tersebut didasarkan pada kondisi komorbiditas dan tingkat keparahan penyakit ginjal. Hasil yang sama juga didapatkan oleh Balci et al. ${ }^{4}$ yang melaporkan pasien yang mengalami gangguan kadar natrium; 60\% diantaranya ialah hiponatremia.

Menurut Craig, ${ }^{12}$ hiponatremia merupakan gangguan elektrolit yang paling umum, terutama pada pasien rumah sakit. Hiponatremia juga ditemukan pada sekitar $30 \%$ dari pasien yang dirawat di unit perawatan intensif. Hiponatremia didapat pada $42,6 \%$ pasien di sebuah rumah sakit Singapura dan 30\% dari pasien yang dirawat di Rotterdam.

Pada Tabel 9, terdapat 17 pasien rawat jalan dan 18 pasien rawat inap. Pada pasien rawat jalan, 9 orang mengalami penurunan kadar natrium (52,9\%), 5 orang dengan kadar natrium masih normal (29,4\%), dan 3 orang mengalami peningkatan kadar natrium (17,6\%). Pada pasien rawat inap, terdapat 10 orang mengalami penurunan kadar natrium (55,6\%), 5 orang dengan kadar natrium masih normal (27,8\%), dan 3 
orang mengalami peningkatan kadar natrium $(16,7 \%)$.

Kehilangan natrium yang abnormal dalam urin dapat terjadi pada PGK. Pada awal fase pemulihan dengan pemberian diuretik, natrium cenderung menglami defisit yang tinggi. Pasien memiliki kemampuan terbatas untuk mengurangi ekskresi natrium dalam kurangnya asupan. Kadar natrium akan semakin berkurang jika asupan dibatasi oleh kurangnya nafsu makan, mual, dan muntah. Pengurangan kadar yang besar dapat terjadi secara diamdiam selama beberapa hari atau minggu. Hasilnya adalah penurunan kadar natrium akan mengganggu fungsi ginjal. ${ }^{13}$

Hiponatremia biasanya tidak terjadi pada laju filtrasi glomerulus di atas $10 \mathrm{ml}$ / menit. Jika itu terjadi, asupan cairan yang berlebihan atau pelepasan vasopresin oleh rangsangan seperti nyeri, anestesi, atau penggunaan diuretik. Faktor risiko lain dari hiponatremia ialah usia lanjut, jenis kelamin pria, berat badan rendah dan pada populasi panti jompo juga asupan cairan hipotonik dan diet rendah natrium. Hiponatremia berhubungan dengan peningkatan bermakna pada mortalitas pasien rawat inap. ${ }^{12}$

Pada Tabel 10, terdapat 8 orang yang mengalami penurunan kadar klorida (22,9\%), 19 orang dengan kadar klorida masih normal $(54,3 \%)$, dan 8 orang terjadi peningkatan kadar klorida (22,9\%). Artinya sekitar 45,8\% pasien mengalami gangguan kadar klorida (hipokloremia dan hiperkloremia) dan 54,3\% pasien masih dalam batas normal.

Menurut hasil penelitian retrospektif Tani et al. ${ }^{5}$, distribusi tingkat klorida yang didapat ialah hiperkloremia 16,6\%, normokloremia 74,6\%, dan hipokloremia 8,8\%. Tani et al. $^{5}$ melakukan studi observasional pada 488 pasien untuk menyelidiki kejadian gangguan kadar klorida, efek dari hipokloremia pada gangguan asam-basa, dan hubungan antara klorida dan hasil klinis. Penelitian ini melibatkan analisis gas darah arteri, data biokimia dan analisis kuantitatif asam-basa. Untuk analisis statistik, pasien dikelompok- kan menjadi tiga kelompok sesuai dengan tingkat klorida mereka (batas normal: 97$111 \mathrm{mmol} / \mathrm{L}$ ).

Pada Tabel 11, terdapat 17 pasien rawat jalan dan 18 pasien rawat inap. Pada pasien rawat jalan, 3 orang mengalami penurunan kadar klorida (17,6\%), 11 orang dengan kadar klorida masih normal (64,7\%), dan 3 orang mengalami peningkatan kadar klorida (17,6\%). Pada pasien rawat inap, terdapat 4 orang mengalami penurunan kadar klorida (22,2\%), 10 orang dengan kadar klorida masih normal (55,6\%), dan 4 orang mengalami peningkatan kadar klorida (22,2\%).

Klorida adalah sebuah anion halogen anorganik yang didistribusikan secara eksklusif dalam cairan ekstrasel (ECF) pada kompartemen darah/plasma (atau serum) dan kompartemen cairan interstitial. Klorida merupakan anion utama yang terkait dengan natrium dalam cairan ekstraseluler. $^{14}$

Menurut Morrison, ${ }^{15}$ penurunan kadar klorida terjadi karena konsentrasi klorida yang kurang pada urin. Hal ini disebabkan karena penyalahgunaan diuretik. Kadar klorida yang rendah disebabkan oleh hilangnya volume asam klorida dari ginjal karena diuretik atau kehilangan garam akibat nefropati (Sindrom Bartter dan Gitelman). Hipokloremia juga sering terjadi bersamaan dengan hiponatremia. Kondisi hiperkloremia juga bisa terjadi pada PGK. Kadar klorida biasanya meningkat pada asidosis metabolik anorganik dan menandakan normal anion gap metabolic asidosis (Nagma). Penyebab hiperkloremia ialah infus intravena tinggi klorida seperti 0,9\% salin normal, dan obat-obatan seperti anhydrase inhibitor karbonat, dan $\mathrm{ENaC}$ blockers (triamterene, amilorid).

\section{SIMPULAN}

Berdasarkan hasil penelitian ini dapat disimpulkan bahwa pada penyakit ginjal kronik stadium 5 non-dialisis terjadi gangguan keseimbangan kadar natrium dan klorida dengan hiponatremia yang tersering ditemukan sedangkan hipokloremia dan 
hiperkloremia memiliki jumlah kejadian yang sama. Penyakit ginjal kronik banyak terjadi pada usia 66-75 tahun, dan jenis kelamin laki-laki lebih banyak dibandingkan perempuan.

\section{UCAPAN TERIMA KASIH}

Ucapan terimakasih disampaikan kepada Dr. dr. Arthur E. Mongan, MSc, SpPK dan kepada semua pihak yang baik secara langsung maupun tidak langsung telah menumbuhkan ide atau gagasan dalam pemikiran penulis.

\section{DAFTAR PUSTAKA}

1. Suwitra K. Penyakit ginjal kronik. In: Sudoyo Aru W, Setiyohadi Bambang, Alwi Idrus, editors. Buku Ajar Ilmu Penyakit Dalam Jilid I (4th ed). Jakarta: Pusat Penerbitan Departemen Ilmu Penyakit Dalam FKUI, 2006; p. 570-3.

2. Heerspink HJL, Navis G, Ritz E. Salt intake in kidney disease - a missed therapeutic opportunity? Nephrol Dial Transplant. 2012;27:3435-3442.

3. Yaswir R, Ferawati I. Fisiologi dan gangguan keseimbangan natrium, kalium dan klorida serta Pemeriksaan Laboratorium. Jurnal Kesehatan Andalas. 2012;1(2):80-5.

4. Balci AK, Koksal O, Kose A, Armagan E., Ozdemir F, Inal T, dkk. General characteristics of patients with electrolyte imbalance admitted to emergency department. Word J Emerg Med. 2013;4(2):113-6.

5. Tani M, Morimatsu H, Takatsu F, Morita $\mathbf{K}$. The incidence and prognostic value of hypochloremia in critically ill patients. The Scientific World Journal. 2012;2012:1-7.

6. United State Renal Data System. 2015 USRDS Annual Data Report Volume 2: ESRD in the United States. 2015. Available from: http://www.usrds.org/2015/view/v2_0 1.aspx

7. Badan Penelitian dan Pengembangan Kesehatan Kementrian Kesehatan RI. Riset Kesehatan Dasar tahun 2013. Jakarta. 2013;p. 129-31.

8. Nicola L, Minutolo R, Chiodini P, Borrelli S, Zoccali C, Postorino M, et al. The effect of increasing age on the prognosis of non-dialysis patientswith chronic kidney disease receiving stable nephrology care. Kidney International. 2012;82:482-8.

9. Perkumpulan Nefrologi Indonesia (PERNEFRI). $5^{\text {th }}$ Report of Indonesia Renal Registry. PERNEFRI. 2012. Available from: www.pernefriinasn.org/Laporan/5th Annual Report Of IRR 2012.pdf

10. Buffet L, Ricchetti C. Chronic kidney disease and hypertension: a destructive combination. US Pharmacist. 2012;59(suppl 1):1-7.

11. Kovesdy CP. Significance of hypo- and hypernatremia in chronic kidney disease. Nephrol Dial Transplant. 2012;27:891-8.

12. Craig S. Hyponatremia in emergency medicine. Medscape Reference: Drugs, Diseases \& Procedures. 2015. Available from: http://emedicine.medscape.com/articl e/767624-overview

13. Levinsky NG. Fluids and electrolytes. In: Thorn GW, Adams RD, Braunwald $\mathrm{E}$, Isselbacher KJ, Petersdorf RG, editors). Harrison's Principle of Internal Medicine (8th ed). McGrawHill, Inc.; 1977; p. 366-7.

14. Goel N. Chloride and its clinical implications in today's clinical practice: not an orphan electrolyte. J Nephrol Ther. 2015;5(6):1-4.

15. Morrison G. Serum chloride. In: Walker HK, Hall WD, Hurst JW, editors. Clinical Methods: The History, Physical, and Laboratory Examinations (3rd ed). Boston: Butterworths, 1990; p. 892. 